\title{
MILLENIALS LIFESTYLE PHENOMENON DAN STORE ATMOSPHERE TERHADAP BUYING DECISION
}

\author{
Sulastri Fazriah $^{1}$, Nor Norisanti ${ }^{2}$, Kokom Komariah $^{3}$ \\ Universitas Muhammadiyah Sukabumi ${ }^{1,2,3}$ \\ fazriah49@gmail.com ${ }^{1}$
}

\begin{abstract}
ABSTRAK
Tujuan dalam penelitian ini yaitu untuk mengetahui pengaruh life styledan store atmosphere terhadap buying decision. Penggunaan metode dalam penelitian ini adalah menggunakan jenis sampling termasuk kedalam sampel random sampling dan dengan melakukan penyebaran kuesioner sebanyak 100 kepada konsumen. Teknik analisis yang digunakan adalah teknik analisis linear berganda, dan untuk pengujian hipotesis adalah uji statistik secara simultan (uji f). Berdasarkan hasil uji F nilai probabilitas sig $0,000<$ 0,1. Simpulan, life style (X1) dan Store Atmosphere (X2) berpengaruh signifikan terhadap buying decision (Y).
\end{abstract}

Kata Kunci: Buying Decision, Life style, Store Atmosphere

\section{ABSTRACT}

The purpose of this study was to determine the effect of store lifestyle on purchasing decisions. The research method in this study uses the type of sample included in the random sampling sample and by distributing questionnaires as many as 100 to consumers. The analysis technique used is multiple linear analysis techniques, and for hypothesis testing is a statistical test using simultaneous ( $f$ test). Based on the results of the $F$ test the probability value sig 0,000<0.1. In conclusion, life style (X1) and Store Atmosphere (X2) have a significant effect on purchasing decisions $(Y)$.

Keywords: Purchasing Decisions, Lifestyle, Store Atmosphere

\section{PENDAHULUAN}

Persaingan dunia bisnis di era moderanisasi seperti sekarang ini semakin sengit, dimana pengusaha di tuntut untuk mampu bersaing dalam menciptakan sesuatu yang inovatif dan mampu mendatangkan banyak konsumen. Ada banyak sekali macam bisnis yang bisa di jadikan sebagai peluang usaha, salah satu usaha yang sedang marak di kalangan pelaku bisnis kuliner dengan membuka sebuah coffee shop. Dimana kehadiran coffee shop di nilai sesuai dengan kebutuhan dangaya hidup masyarakat. Tentunya di sertai dengan fasilitas-fasilitas memadai yang akan menarik konsumen untuk melakukan pembelian. Salah satu keputusan pembelian yang dilakukan konsumen ialah pada saat pembelian nya pada sebuah coffee shop. Banyak dari konsumen yang sudah mengetahui 
coffee shop. Biasanya konsumen akan mengunjungi coffe shop yang mampu memberikan daya tarik tersendiri

Banyak nya coffee shop di Sukabumi juga membuat setiap pengusaha kuliner yang membuka coffee shop harus lebih bisa bersaing, apalagi dengan muncul nya masyarakat milenial, masyarakat yang lahir pada kisaran tahun 1980-1996 dan sangat mahir dalam penggunaan terknologi. Masyarakat milenial menjadikan kegiatan mengunjungi coffee shop sebagai bagian dari gaya hidupdan kebutuhan hidup yang harus dipenuhi. Karena dengan adanya kegiatan tersebut masyarakat milenial merasa akan lebih relax kembali setelah meluangkan sedikit waktunya untuk melakukan kegiatan tersebut. Masyarakat milenial menyukai hal-hal yang dianggap menarik dan unik, seperti pada saat menikmati kopi di sebuah coffee shop.

Banyak dari konsumen yang datang ke sebuah coffee shop bukan hanya berniat untuk mencicipi menu yang ada di coffee shop yang bersangkutan, namun sekedar untuk foto dengan alasan coffe shop yang bersangkutan memiliki suasana (atmosphere) yang bagus dan menarik untuk di jadikan spot foto, karena konsumen saat ini lebih tertarik dengan tempat-tempat yang instagramable.

Permasalahan yang terjadi pada sebuah coffee shop salah satunya adalah pada keputusan pembelian. Munculnya ketidakpuasan pasca melakukan keputusan pembelian biasanya disebabkan karena pemilik usaha (owner) kurang memeperhatikan gaya hidup masyarakat yang selalu berkembang setiap waktunya, sehingga konsumen seringkali merasa jenuh dengan menu atau penyajian yang monoton atau itu-itu saja. Adapun faktor lain disebabkan oleh store atmosphere yang kurang menarik perhatian konsumen, hal tersebut merupakan faktor yang sangat penting untuk diperhatikan, sebab dapat merangsang terjadinya keputusan pembelian.

\section{TINJAUAN PUSTAKA}

\section{Pemasaran}

Kegiatan suatu perusahaan memiliki aktivitas pemasaran yang sangat penting, artinya bagi pencapaian tujuan sesuai dengan yang diharapkan, karena aktivitas pemasaran diarahkan untuk menciptakan perputaran yang memungkinkan perusahaan dapat mempertahankan kelangsungan hidup untuk berkembang dan mendapatkan keuntungan bagi perusahaan. Pengertian pemasaran menurut Kotler, Keller (2016) 
pemasaran adalah fungsi organisasi dan serangkaian proses untuk menciptakan, berkomunikasi, dan memberikan nilai pada hubungan pelanggan dengan cara yang menguntungkan organisasi dan pemangku kepentingannya.

Menurut American Marketing Association dalam Kotler, Keller (2014) menyatakan bahwa Pemasaran adalah suatu fungsi organisasi dan serangkaian proses untuk menciptakan, mengkomunikasikan, dan memberikan nilai kepada pelanggan dan untuk mengelola hubungan pelanggan dengan cara yang menguntungkan organisasi dan pemangku kepentingannya.

\section{Manajemen Pemasaran}

Manajemen Pemasaran adalah proses penetapan tujuan-tujuan pemasaran bagi suatu organisasi (dengan mempertimbangkan sumber daya internal dan peluang pasar), perencanaan, dan pelaksanaan aktivitas untuk memenuhi tujuan-tujuan tersebut, dan mengukur kemajuan ke arah pencapaiannya. Perusahaan memerlukan berbagai cara untuk dapat mengatur kegiatan pemasarannya agar sesuai dengan tujuan perusahaan yang telah ditentukan, dalam hal ini pengaturan yang diperlukan perusahaan adalah manajemen pemasaran.

Menurut Murti Sumarni dalam Danang Sunyoto (2014) Manajemen pemasaran adalah analisis, perencanaan, pelaksanaan dan pengendalian atas program yang dirancang untuk menciptakan, membentuk dan mempertahankan pertukaran yang menguntungkan dengan pembeli sasaran (target buyers) dengan maksud untuk mencapai tujuan-tujuan organisasional.

\section{Bauran Pemasaran}

Bauran pemasaran merupakan unsur unsur pemasaran yang dapat dikendalikan dan digunakan oleh suatu perusahaan untuk mencapai tujuan pemasaran dalam pasar sasaran. Bauran pemasaran memiliki unsur penting dalam mempengaruhi keputusan pembelian konsumen agar dapat tertarik untuk membeli suatu produk atau jasa yang ditawarkan.

Menurut Kotler, Keller (2016) dalam bauran pemasaran terdapat seperangkat alat pemasaran yang dikenal dalam istilah 4P, yaitu product (produk), price (harga), place (tempat atau saluran distribusi), dan promotion (promosi). Adapun pengertian 4P 
yaitu: (1) Produk (product) adalah mengelola unsur produk termasuk perencanaan dan pengembangan produk atau jasa yang tepat untuk dipasarkan dengan mengubah produk atau jasa yang ada dengan menambah dan mengambil tindakan yang lain yang mempengaruhi bermacam-macam produk atau jasa. (2) Harga (price) adalah suatu sistem manajemen perusahaan yang akan menentukan harga dasar yang tepat bagi produk atau jasa dan harus menentukan strategi yang menyangkut potongan harga, pembayaran ongkos angkut dan berbagi variabel yang bersangkutan. (3) Distribusi (place) adalah memilih dan mengelola saluran perdagangan yang dipakai untuk menyalurkan produk atau jasa dan juga untuk melayani pasar sasaran, serta mengembangkan sistem distribusi untuk pengiriman dan perniagaan produk secara fisik. (4) Promosi (promotion) adalah suatu unsur yang digunakan untuk memberitahukan dan membujuk pasar tentang produk atau jasa yang baru pada perusahaan melalui iklan, penjualan pribadi, promosi penjualan, maupun publikasi.

\section{Perilaku Konsumen}

Di era yang serba modern ini juga persaingan pasar sangat ketat sehingga mendorong perusahaan untuk lebih kreatif dan inovatif lagi dalam memasarkan produk mereka. Salah satu nya perusahaan harus bisa memahami bagaimana prilaku konsumen nya. Prilaku konsumen bisa di artikan sebagai suatu proses dan aktifitas yang berhubungan dengan pembelian, keinginan, pemilihan, pencarian pada produk atau jasa yang dapat memenuhi keinginan dan kebutuhan seseorang.Kotler \& Keller (2016) menggambarkan model perilaku konsumen sebagai berikut:

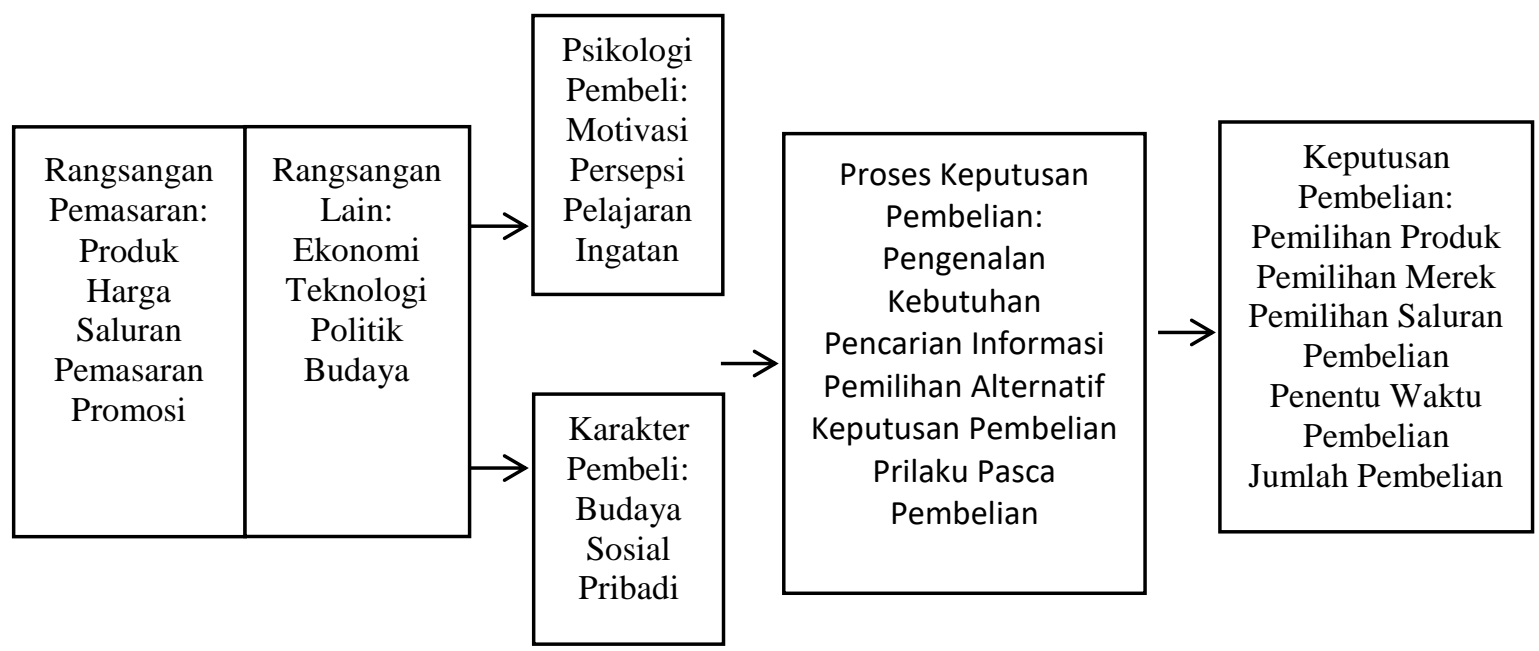

Sumber: Kotler dan Keller (2016) 


\section{Lifestyle}

Gaya hidup secara luas bisa di artikan tentang bagaimana seseorang menghabiskan waktu mereka (aktivitas), apa yang mereka anggap penting dalam lingkungannya (ketertarikan), dan apa yang mereka pikirkan tentang diri mereka sendiri dan juga dunia disekitarnya (pendapat). Gaya hidup juga mencerminkan bagaimana seseorang menghabiskan waktu dan uang nya untuk memenuhi keinginan dan kebutuhan.

Menurut Setiadi dalam Arif (2018) dimensi gaya hidup gaya hidup akan berkembang pada masing-masing dimensi (aktivitas, interest, opini / AIO): (1) Kegiatan (Activity) adalah apa yang dikerjakan konsumen, produk apa yang dibeli atau digunakan, kegiatan hobi atau hiburan apa yang dilakukan untuk mengisi waktu luang. (2) Minat (Interest) dapat berupa kesukaan, kegemaran dan prioritas dalam hidup konsumen tersebut. (3) Opini (Opinion) adalah pandangan dan perasaan konsumen terhadapdirinya atau orang lain serta terhadap dunia sekitarnya.

\section{Milenial}

Pada masa ini masyarakat sedang marak membicarakan tentang generasi milenial. Menurut Shiffman, Wisenblit (2015) Generasi Y atau disebut dengan generasi milenial adalah generasi yang lahir pada kisaran tahun 1980-1996. Namun beberapa lahir pada kisaran akhir tahun 1970 dan akhir 1990. Gen Y tumbuh dengan teknologi yang sudah semakin canggih, generasi ini tertarik dengan stimulasi yang lebih tinggi dan cenderung lebih mudah bosan. Generasi ini juga mempunyai kepercayaan diri yang lebih tinggi di banding dengan generasi sebelum nya.

Gaya "kekinian" seperti inilah yang dilakukan oleh kalangan muda generasi milenial. Menurut Strauss dan How (2000) generasi milenial adalah masayarakat yang lahir pada kurun waktu 1982- 2000.

\section{Store Atmosphere}

Menurut Kartika, Syahputra (2017) "Store atmosphere adalah suatu kombinasi karakteristik fisik restoran seperti arsitektur, tata ruang, papan tanda dan pajangan, pewarnaan, pencahayaan, suhu udara, suara dan aroma, yang mana karakteristik tersebut saling bekerja sama untuk menciptakan citra perusahaan di dalam benak pelanggan.” 
Dimensi Store Atmosphere Menurut Berman, Evans (2011) (1) Bagian luar toko (exterior) Bagian luar toko adalah merupakan keseluruhan fisik bagian luar toko yang memberikan kesan menarik. Exterior meliputi keseluruhan bangunan fisik yang dapat dilihat dari bentuk bangunan, pintu masuk, fasilitas parkir dan lain-lain. (2) Bagian dalam toko (Interior)Interior merupakan penampilan bagian di dalam suatu toko yang tidak kalah pentingnya untuk menarik konsumen, faktor interior ini meliputi penerangan di dalam toko, kondisi ruangan, suhu udara, aroma ruangan, suara musik dan lain-lain. (3) Tata letak toko (store layout)Tata letak toko merupakan pengaturan secara fisik penempatan dan penataan barang dan tata letak barang didalam toko. (4) Dekorasi Pemikat Dalam Toko (display)Display adalah suatu dekorasi ruangan yang sesuai tema dapat menjadi ciri khas dan dapat memikat konsumen.

\section{Buying Decisison}

Keputusan pembelian adalah sebuah sikap yang di ambil oleh konsumen melalui beberapa proses, dari mulai pengintegrasian dan mengevaluasi berbagai alternative dalam menentukan pilihan yang tepat untuk memenuhi keinginan atau kebutuhan konsumen tersebut. Proses Keputusan pembelian dapat di ambil hanya jika ada beberapa alternatif pilihan. Apabila tidak ada beberapa alternatif maka tindakan pengambilan keputusan tidak bisa dilakukan.

Menurut Kotler, Keller (2016) ada lima dimensi yang menjadi tahapan proses keputusan pembelian: (1) Pengenalan kebutuhan: ketika pembeli menyadari adanya masalah/kebutuhan. Pembeli merasakan adanya perbedaan antara keadaan aktual dengan keadaan yang diinginkannya. Kebutuhan ini dapat dipicu oleh stimuli internal maupun eksternal. (2) Pencarian informasi: ketika seorang konsumen yang tergerak oleh stimuli akan berusahan untuk mencari lebih banyak informasi. Keadaan pencarian informasi yang lebih ringan disebut perhatian yang memuncak (heightened attention). (3) Evaluasi alternatif: bagaimana konsumen memproses informasi mengenai merek yang bersaing dan membuat pertimbangan akhir mengenai nilainya. Konsumen memandang setiap produk sebagai sekumpulan atribut (a bundle of attributes) dengan kemampuan yang berbeda-beda dalam memberikan manfaat yang dicari dan memuaskan keinginan serta kebutuhan tersebut. (4) Keputusan pembelian: keputusan pembelian adalah tindakan dari konsumen yang memastikan untuk membeli atau tidak. 
Dalam tahap evaluasi, konsumen membentuk preferensi diantara merek-merek dalam kelompok pilihan. (5) Perilaku pasca pembelian: setelah membeli produk konsumen akan merasakan tingkat kepuasan atau ketidakpuasan tertentu. Konsumen juga akan melakukan tindakan pasca pembelian dan menggunakan kembali produk tersebut.

\section{METODE PENELITIAN}

Metode yang digunakan dalam penelitian ini adalah menggunakan jenis sampling termasuk kedalam nonprobability sampling dengan teknik sampling purposive dengan melakukan penyebaran kuesioner kepada 100 orang konsumen. Teknik analisis yang digunakan adalah teknik analisis regresi linear berganda, termasuk uji koefisien determinasi, koefisien korelasi ganda dan uji secara simultan (uji F).

\section{HASIL PENELITIAN}

\section{Uji Koefisien Determinasi $\left(\mathbf{R}^{2}\right)$}

Tabel 1 Hasil Uji Koefisien Determinasi $\left(\mathrm{R}^{2}\right)$

\begin{tabular}{lllll}
\hline Model & R & R Square & Adjusted R Square & Std Error of the Estimate \\
\hline 1 & $0,725^{\text {a }}$ & 0,525 & 0,516 & 2,620
\end{tabular}

Sumber: Data Olahan, 2019

Untuk mengetahui pengaruh gaya hidup dan store atmosphere dalam keputusan pembelian, maka dilakukan perhitungan koefesien determinasi dengan rumus sebagai berikut:

$$
K d=r^{2} \times 100 \%
$$

Dimana:

$\mathrm{Kd}=$ Koefisien determinasi

$\mathrm{r} \quad=$ Koefisien korelasi

Diketahui:

$\mathrm{r} \quad=0,725$

$\mathrm{Kd}=(0,725)^{2} \times 100 \%$

$\mathrm{Kd}=0,520 \times 100 \%$

$\mathrm{Kd}=52 \%$ 
Adapun criteria untuk koefisien determinasi ialah sebagai berikut:

1. Jika "kd" mendekati 0 , maka pengaruh variabel $\mathrm{X} 1$ dan $\mathrm{X} 2$ terhadap variabel $\mathrm{Y}$ lemah.

2. Jika "kd" mendekati 1, makapengaruhvariabel X1 dan X2 terhadapvariabel Y kuat.

Berdasarkan perhitungan koefisien determinasi yang telah peneliti lakukan, diketahui bahwa nilai $\mathrm{Kd}=52 \%$. Maka dapat disimpulkan bahwa pengaruh gaya hidup dan store atmosphere dalam proses keputusan pembelian yaitu kuat.

\section{Uji Signifikan secara Simultan (uji F)}

Tabel 2 Hasil Uji Simultan (F)

\begin{tabular}{lllllll}
\hline Model & & Sum of Squares & df & Mean Square & F & Sig. \\
\hline 1 & Regression & 737.350 & 2 & 368.675 & 53.693 & $.000^{\mathrm{b}}$ \\
& Residual & 666.040 & 97 & 6.886 & & \\
& Total & 1403.390 & 99 & & &
\end{tabular}

Sumber: Data Olahan 2019

Berdasarkan tabel di atas, hasil uji $\mathrm{F}$ yang dilakukan dapat diperoleh nilai signifikan $0,000<0,01$; nilai $\mathrm{F}_{\text {hitung }} 3,555>\mathrm{F}$ tabel 2,36 artinya bahwa lifestyle dan store atmosphere secara bersama-sama (simultan) berpengaruh terhadap buying decision, maka dapat disimpulkan $\mathrm{H}_{1}$ diterima dan $\mathrm{H}_{0}$ ditolak.

Dari hasil hitungan penelitian analisis regresi linear berganda dengan uji $\mathrm{F}$ dengan tingkat signifikan sebesar $10 \%(0,1)$ menunjukan bahwa lifestyle dan store atmosphere berpengaruh secara bersama-sama terhadap buying decision. Hal ini ditunjukan dari hasil nilai sig. $0,000<0,1$; nilai $F_{\text {hitung }} 53,693>F_{\text {tabel }} 2,36$. Nilai koefisien determinasi $\left(\mathrm{R}^{2}\right)$ dari lifestyle dan store atmosphere mempengharuhi sebesar $90 \%$ sisanya $10 \%$ dipengaruhi oleh faktor lain diluar penelitian. Hal ini dikarenakan lifestyle dan store atmosphere berperan penting terhdapa buying decision. Dengan demikian, dapat diketahui bahwa lifestyle dan store atmosphere merupakan faktor yang yang mempengaruhi terjadinya buying decision pada C'Kopi Gaud Sukabumi. 


\section{Koefisien Korelasi Ganda}

Tabel 3 Hasil Uji Koefisien Korelasi Ganda

\begin{tabular}{lllll}
\hline Model & R & R Square & $\begin{array}{l}\text { Adjusted } \\
\text { Square }\end{array}$ & $\begin{array}{l}\text { R Std. Error of } \\
\text { the Estimate }\end{array}$ \\
\hline 1 & $.725^{\text {a }}$ & .525 & .515 & 2.620 \\
\hline Sumber: Data Olahan 2019 & &
\end{tabular}

Berdasarkan hasil tabel model summary di atas menunjukan bahwa besarnya adjusted $\mathrm{R}$ adalah 0.725 berada pada kategori 0,60 - 0,799. Hal ini menunjukan bahwa terjadinya hubungan yang kuat antara Lifestyle dan Store Atmosphere terhadap Buying Decision.

\section{Analisis Regresi Linear Berganda}

\begin{tabular}{|c|c|c|c|c|c|c|}
\hline \multicolumn{2}{|c|}{ Model } & \multicolumn{2}{|c|}{ Unstandardized Coefficients } & \multirow{2}{*}{$\begin{array}{l}\text { Standardized } \\
\text { Coefficients }\end{array}$} & \multirow[t]{3}{*}{$\mathrm{t}$} & \multirow[t]{3}{*}{ Sig. } \\
\hline & & & & & & \\
\hline & & B & Std. Error & Beta & & \\
\hline \multirow[t]{3}{*}{1} & (Constant) & 2.634 & 1.904 & & 1.384 & .170 \\
\hline & Lifestyle & .230 & .090 & .180 & 2.557 & .012 \\
\hline & Store Atmosphere & .356 & .356 & .686 & 9.765 & .000 \\
\hline
\end{tabular}

Sumber: Data Olahan 2019

Berdasarkan data dari table diatas, dapat diketahui persamaan regresi dari gaya hidupdan store athmosphere dalam keputusan pembelian yaitu sebagai berikut:

$\begin{array}{ll}\mathrm{b}_{1} & =0,180 \\ \mathrm{~b}_{2} & =0,666\end{array}$

Selanjutnya didapat persamaan regresi linear berganda untuk dua predicator yaitu gaya hidup dan store atmosphere adalah sebagai berikut:

$Y=\beta X_{1}+\beta X_{2}+\mu$

$Y=0,180 X_{1}+0,666 X_{2}+\mu$ 


\section{PEMBAHASAN}

\section{Pengaruh Life Style terhadap Buying Decision}

Diketahui bahwa variabel life style memiliki pengaruh yang positif dan signifikan terhadap buying decision konsumen di C'Kopi Gaud Sukabumi. Dapat dilihat dari tanggapan responden mengenai minat konsumen pada menut di C'Kopi Gaud Sukabumi, mengingat bahwa setiap orang memiliki gaya hidup yang berbeda-beda, seperti gaya hidup milenial yang sedang marak sekarang, gaya hidup milenial mempengaruhi budaya konsumsi. seperti pada menu dia sebuah coffee shop, konsumen milenial biasanya akan melakukan pembelian pada sesuatu yang unik dan menarik dan pastinya kekinian. Sebagaimana yang diungkapkan oleh Silvya (2009) dalam Sunarti dan Pangestuti (2018) Gaya hidup akan mempengaruhi keinginan seseorang untuk berperilaku dan akhirnya menentukan pilihan-pilihan konsumsi seseorang. Gaya hidup yang merupakan bagian dari perilaku kosnumen juga mempengaruhi tindakan konsumen dalam melakukan pembelian. Dari hasil penelitian yang dilakukan oleh peneliti terdahulu yaitu Arif (2018) gaya hidup konsumen berpengaruh secara serempak maupun secara parsial terhadap keputusan pembelian di Soban Cafe Medan. Penelitian sebelumnya sejalan dengan penelitian yang dilakukan saat ini bahwa variabel life style berpengaruh positif dan signifikan terhadap buying decision pada konsumen C'Kopi Gaud Sukabumi.

\section{Pengaruh Store Atmosphere terhadap Buying Decision}

Diketahui bahwa variabel store atmosphere memiliki pengaruh yang positif dan signifikan terhadap buying decision konsumen di C'Kopi Gaud Sukabumi. Dapat dilihat dari tanggapan responden yang baik mengenai tempat C'Kopi Gaud Sukabumi yang strategis berada di pusat kota Sukabumi, lantunan musik yang disajikan C'Kopi Gaud enak di dengar, aroma C'Kopi Gaud sudah wangi, penataan barang-barang C'Kopi Gaud juga sudah tepat dan rapih. Hanya saja konsumen merasa tidak nyaman dengan pencahaan nya yang kurang baik, dekorasi yang tidak menarik dan tempat parker yang kurang luas. Sebagaimana yang diungkapkan oleh Levy \& Weitz (dalam Kartika dan syahputra 2017) adanya hubungan Store Atmosphere dengan Keputusan Pembelian, Store Atmosphere bertujuan untuk menarik perhatian konsumen untuk berkunjung, memotivasi mereka untuk membuat perencanaan secara mendadak, mempengaruhi 
mereka untuk melakukan pembelian, dan memberikan kepuasan dalam berbelanja. Dengan demikian, dapat disimpulkan bahwa store atmosphere yang dilaksanakan dengan baik akan memberikan pengaruh positif terhadap keputusan pembelian oleh konsumen. Dari hasil penelitian yang dilakukan oleh peneliti terdahulu Purnomo (2017) menyatakan bahwa elemen tata letak toko dan bagian luar (eksterior) pada variabel store atmosphere berpengaruh terhadap keputusan pembelian konsumen Gen Y pada Old Café Bandung.

\section{SIMPULAN}

Berdasarkan hasil penelitian, dapat ditarik kesimpulan: (1) Gaya hidup milenial pada konsumen C'Kopi Gaud Sukabumi, melalui pengukuran dimensi activity, interest, opinion secara keseluruhan dapat dikatakan sudah baik dalam mendorong konsumen untuk melakukan keputusan pembelian. Namun masih terdapat responden yang menjawab ragu-ragu terhadap dimensi minat (interest) yang menyatakan mengenai menu C'Kopi Gaud Sukabumi yang menarik untuk konsumen nya.

(2) Store athmosphere pada C'Kopi Gaud Sukabumi, melalui pengukuran dimensi eksterior, interior, store layout dan interior display secara keseluruhan dapat dikatakan sudah baik dalam mendorong konsumen untuk melakukan keputusan pembelian. Namun masih terdapat responden yang menjawab tidak setuju terhadap pernyataan mengenai bagian interior C'Kopi Gaud Sukabumi yang menyatakan pencahayaan pada C'Kopi Gaud Sukabumi sudah baik dan terdapat responden yang menjawab tidak setuju pada bagi eksterior terutama pada penyediaan lahan parkir yang dirasa masih kurang baik dan tidak aman.

(3) Proses keputusan pembelian pada C'Kopi Gaud Sukabumi, melalui pengukuran dimensi pengenalan kebutuhan, pencarian informasi, evaluasi alternative, keputusan pembelian dan perilaku pasca pembeliansecara keseluruhan dapat dikatakan sudah baik. Namun masih terdapat konsumen yang menjawab ragu-ragu terhadap pernyataan kepuasan terhadap C'Kopi Gaud. Masih banyak reponden yang merasa kurang puas dengan pelayanan pada C'Kopi Gaud.

(4) Berdasarkan hasil uji hipotesis secara simultan menunjukan bahwa fenomena gaya hidup milenialdan store athmosphere berpengaruh positif dan signifikan dalam proses keputusan pembelian pada C'Kopi Gaud Sukabumi. Hal tersebut dapat 
disimpulkan setelah pengujian hipotesis serta hal-hal lain yang mempengaruhi proses keputusan pembelian pada C'Kopi Sukabumi yang dipengaruhi oleh faktor lain yang tidak diteliti dalam penelitian ini.

\section{DAFTAR PUSTAKA}

Arif, M., Nurlaila, N., Lubis, F. A. (2018). Pengaruh Store Atmofer, Lokasi dan Gaya Hidup Terhadap Keputusan Pembelian Di Soban Café Medan. Skripsi. Universitas Islam Negeri Sulawesi Utara

Berman, B., Evans, R. J. (2011). Retailing Management. $11^{\text {th }}$ edition, Boston: Pearson.

Cetakan Ke Dua. Yogyakarta: CAPS

Howe, N \& Strauss, W. (2000). Millennials Rising. New York : Vintage Books Jersey: Pearson Prentice Hall.

Kartika, D. M., Syahputra, S. (2017). Pengaruh Store Atmosphere terhadap Keputusan Pembelian Coffe Shop di Bandung. Jurnal Ekonomi, Manajemen \& Bisnis Universitas Bina Sarana Informatika, 2(2), 162-171

Kotler, P., Armstrong, G. (2014). Principle of Marketing. 15th edition. New

Kotler, P., Keller, K. L. (2016). Marketing Management. $15^{\text {th }}$ Edition, Person Education, Inc

Purnomo, A. K. (2017). Pengaruh Café Atmosphere terhadap Keputusan Pembelian Gen Y pada Old Bens Cafe. Jurnal Manajemen Maranatha, 16(2), 133-144

Schiffman, L. G., Wisenblit J. L. (2015). Consumer Behavior, $11^{\text {th }}$ Edition, Edinburgh: Pearson Education Limited

Sunyoto, D. (2014). Dasar-Dasar Manajemen Pemasaran (Konsep, Strategi, dan Kasus). Cetakan ke-1. Yogyakarta: CAPS (Center for Academic Publishing Service)

Wijaya, D. N., Sunarti, S., Pangestuti, E. (2018). Pengaruh Gaya Hidup dan Motivasi Terhadap Keputusan Pembelian Survei (Survei pada Konsumen Starbucks, Kota Malang). Jurnal Administrasi Bisnis, 55(2), 75-83 